\title{
From Intersemiotic Translation to Intersemiotic Aspects of Translation
}

\section{Introduction and Aims}

The 1959 paper “On Linguistic Aspects of Translation" (1959/2000), in which Roman Jakobson proposed a division into intralingual, interlingual and intersemiotic translation, proved seminal for the development of the study of translation and for bringing into it a semiotic perspective. However, in the Introduction to the 1998 Routledge Encyclopedia of Translation Studies, Mona Baker noticed that surprisingly little investigation had been conducted on the nature of intersemiotic translation, and that Jakobson's triadic division only "alert[s] us to the possibility of such things as intersemiotic and intralingual translation, but we do not make any genuine use of such classifications in our research" (1998: xvii). Later, Teresa Tomaszkiewicz restated the scarcity of studies of the nature of transmutation, despite the developments in the theorizing of new media and the new forms of translation connected to them (2006: 65-66).

In recent years, among other enquiries into the subject, a comprehensive semiotic classification of translation was proposed by Henrik Gottlieb (2007). Nonetheless, terminological inconsistencies in the discipline are perceptible, which, in turn, can lead to misunderstandings and add to the difficulties in the research. For instance, Tomaszkiewicz cites an example of an intralingual translation being called intersemiotic (2006: 68), while Chiara Moriconi, when writing about the same work being rendered into a different language and into a painting, applies

1 The paper was first published in Przekładaniec. A Journal of Translation Studies 2018, vol. 34-35. (English version: Word and Image in Translation, pp. 7-35, http://dx.doi. org/10.4467/16891864ePC.18.009.9831; Polish version: Przekładaniec 2017, vol.34, pp. 7-35). Reprinted here courtesy of the journal's publisher, Wydawnictwo Uniwersytetu Jagiellońskiego. 
the label "transmutation" to both processes (2014: 62). Even if terms in a given discipline are not neologisms but derive from previous usage - like "translation" and equivalents of this word in many languages - still, in a terminological framework they should be used in an accurate and consistent manner. Otherwise, there will still occur what Edward Balcerzan calls "terminological disturbances in translatology" (2011: 309) (terminologiczne zakłócenia translatologii).

Despite the developments in translation studies, certain phenomena at the interface of translation and semiotics have not been defined unambiguously and with due precision. Therefore, the aim of the present paper is to sketch the distinction between several allied and complementary notions related to intersemioticity, polysemioticity and translation and to illustrate it with examples pertaining to the proposed categories. I postulate that the use of the notion of "intersemiotic translation" be limited in accordance with the name, i.e. exclusively to phenomena of a translational nature and ones that occur between sign systems. This is in no way meant to limit the field of research, but to make it more specific, as will be expounded in the last section. Furthermore, the notions of semiotic complementation and of intersemiotic aspects of translation are put forward.

The starting points will be concepts developed so far and present in current discourse. My propositions will be formulated in an interaction with them. I only remark in advance that my understanding of translation relies on the following premises: translation presupposes a change of code (consequently, something which remains within the same sign system cannot be an instance of translation), with the preservation of some kind of equivalence, which will, however, be defined differently for various kinds of intersemiotic translation, in view of a varying level of homology between the languages of particular arts; translation represents the original (replaces it in the target reception) and it has a single basis.

\section{Intersemiotic Translation}

Roman Jakobson's concept of intersemiotic translation or transmutation has been eagerly embraced across the humanities, and his understanding of translation is perceived as flexible (Clüver 1989: 75). Since 1959, however, new modes of expression have emerged in culture (e.g. computer games), and new types of translation accompany them (e.g. localization). Due to the dynamic developments in both spheres, the concept of transmutation has 
been subject to re-interpretations and redefinitions in semiotic studies as well as in translation studies. The explosion of new cultural phenomena has also lead to an overuse of Jakobson's term and to the blurring of its scope.

To begin with, determining what is and what is not an instance of intersemiotic translation is made more difficult by the scarcity of the original definition. The term that proved so often cited had been introduced almost in passing: Jakobson defines it as "interpretation of verbal signs by means of signs of nonverbal sign systems" (1959/2000: 114) and then provides very general examples of such a transformation: "intersemiotic transposition - from one system of signs into another, e.g., from verbal art into music, dance, cinema, or painting" (1959/2000: 118).

The transformations explicitly named by Jakobson account for the following types of transmutation (unless stated otherwise, examples throughout the paper are mine - M.K.):

- from word to music - programme music (instrumental), e.g. Pyotr Tchaikovsky's The Tempest, Symphonic Fantasia after Shakespeare, op. 18;

- from word to dance - ballets whose librettos derive from verbal arts, like Rodion Shchedrin's Anna Karenina (1971);

- from word to visual arts, e.g. John Everett Millais' Ophelia (18511852, Tate Gallery) or The Death of Ellenai by Jacek Malczewski (paintings based on Juliusz Słowacki's 1838 visionary prose poem Anhelli; cf. one of the versions, from 1907, in the Polish National Museum in Kraków).

The "target" semiotic systems enumerated in the definition also include cinema. Jakobson thus tacitly concedes that the result of the transformation may not only be a change of semiotic system, but also the emergence of a multi-code, ${ }^{2}$ polysemiotic ${ }^{3}$ work - like a film. This probably stems from the fact that cinema from its early days has been treated as an art with its own distinctive, if syncretic, "language" (cf. e.g. Stam, Burgoyne, Flitterman-Lewis 2005: 29ff; Del Grosso 2008: 9-10). In any event, this stance has been embraced both in film studies and in semiotics: film adaptations of literature have been called intersemiotic translations and approached as such (among others: Hopfinger 1974; Cattrysse 1992; Del Grosso 2008).

${ }^{2}$ Nonetheless, in another text he stressed that the study of communication should distinguish between homogeneous messages (using one semiotic system) and syncretic ones - composed of different kinds of signs (Jakobson 1971: 705).

${ }^{3}$ Due to the perspective adopted, what is of interest for me in the present paper is the fact that a work is constituted by a certain number of codes; consequently, I use the descriptions "multicode" and "polysemiotic" (or "bi-semiotic"), which apply to the cases described here. I consciously renounce numerous other terms in circulation, such as "audiovisual", "audiomedial", "multimedial" or "multimodal". 
By the same extension, scholars willingly classify as intersemiotic translations ${ }^{4}$ such polysemiotic phenomena as: theatre adaptations of texts originally not meant for the stage (as well as stagings of dramatic texts themselves), musical-verbal works whose librettos are re-workings of verbal texts (e.g. Hector Berlioz's 1846 dramatic legend The Damnation of Faust, op. 24; André Previn's 1995 opera A Streetcar Named Desire), or - to include more recent genres - computer games based on literary material (e.g. on The Lord of the Rings).

Jakobson's list of "target domains" is not conclusive and additions proposed over time include the following:

- encoding a text into Morse code (cf. Toury 1986: 1117);

- translating into the tactile mode of Braille (cf. Toury 1986: 1117);

- communicating messages by means of systems of flags, etc.;

- informing, prohibiting, commanding, warning by way of conventional pictograms (cf. Tomaszkiewicz 2006: 86-96);

- replacing verbal text with graphic signs (punctuation marks) - as a manifestation of conceptual translation (Brzostowska-Tereszkiewicz 2016: 176-179).

As can benoticed, also from the examples so far, Jakobson's proposition is unidirectional: it only envisages translating from a human language into a non-verbal code. Hence, Jorge Díaz Cintas postulated extending the definition of intersemiotic translation onto the interpretation of nonverbal signs by verbal ones, so that it covered phenomena such as audio description (Díaz Cintas, Desblache 2007; see also Díaz Cintas 2005: 4). Actually, a theoretical framework that assumed unrestricted directionality had already existed. In 1986 Gideon Toury postulated a general binary division into intersemiotic translation (which involves a change of code) and intrasemiotic translation - within the scope of one system of signs (cf. Balcerzan's conclusion to the same effect, 2011: 303). Jakobson's intra- and interlingual translation would both then be branches of the intrasemiotic (Toury 1986: 1114). ${ }^{5}$

${ }^{4}$ A differentiation is, however, postulated by Henrik Gottlieb: between the diasemiotic translation (consisting in changing the semiotic channel) and the categories of super- and hyposemiotic translation, in which the target texts display more or fewer semiotic channels than the original (2007: 35-36).

${ }^{5}$ Umberto Eco, in turn, postulates a tripartite division into intra- and intersystemic interpretation and transcription (with further elaborate subdivisions, 2000: 55-100). In his classification, Eco subjects the notion of translation to the notion of interpretation. NB, he flatly denies translational nature to the use of the Morse code, mentioned above, due to its automatic character: he points out rightly that it is an intralingual "transliteration". 
Toury's framework allows us to classify as transmutation other phenomena:

- a change from music into text, e.g. Kornel Ujejski's "Translations from Chopin" (Ttumaczenia Szopena, a cycle of poems published in 1866);

- from film into (narrative) text, i.e. novelizations of films, e.g. Four Weddings and a Funeral by Richard Curtis from Mike Newell's 1994 film or Rain Man by Leonore Fleischer from Barry Levinson's 1988 production;

- reworking of the visual code into the verbal one, e.g. audio description.

Moreover, by criticizing Jakobson's division as being "readily applicable only to texts" (1986: 1113), Toury implicitly admits cases of "translation" in which (pure) language code is not involved on either side. This would account for extending the notion of transmutation over still more types of transformations:

- from a graphic novel into a film, e.g. $V$ for Vendetta by Alan Moore and David Lloyd $\rightarrow V$ for Vendetta, dir. James McTeigue (2006);

- from a computer game into a film, e.g. Tomb Raider (1996) $\rightarrow$ Lara Croft: Tomb Raider, dir. Simon West (2001);

- from a film into a theatrical performance, like Dziewczyny $z$ kalendarza (staged in Teatr Komedia, Warsaw), based on Calendar Girls, a 2003 film dir. by Nigel Cole;

- from a film into an opera, e.g. The Exterminating Angel composed by Thomas Adés in 2016 on the basis of Luis Buñuel's 1962 film El ángel exterminador;

- from opera to ballet, e.g. Rodion Shchedrin's Carmen Suite (1967), based on Bizet;

- from visual arts to music, e.g. Modest Mussorgsky's Pictures at an Exhibition (1874, inspired by Viktor Hartmann's paintings) or Sergei Rachmaninoff's Isle of the Dead, a tone poem for orchestra (1908, inspired by Arnold Böcklin's Die Toteninsel, 1880-1886);

- from music to visual arts, e.g. Frederic Leighton's Lieder ohne Worte (exhibited 1861, title borrowed from Felix Mendelssohn's op. 30) or Piet Mondrian's [Broadway] Boogie Woogie (1942-1943);

- animation based on music, e.g. Wiesław Bober's realizations of Vivaldi's Le quattro stagioni for the Poznan Animation Studio, 1990-1995.

However, the broadening of the scope of the term should apparently end here. Already the last two categories (music $\leftrightarrow$ visual arts) could perhaps be more appropriately classified as mutual inspirations rather than translations, in view of the distant homologies between the languages of those arts. Admittedly, Gottlieb is willing to consider them translations because he proposes a broad category of inspirational translation (2007: 
36-37, 39). Yet in his framework this class is defined not in absolute terms, but relatively, in opposition to "conventionalized translation" (2007: $36-37,39)$, from which it differs inasmuch as its relation to the original "is more free and less predictable" (2007: 37). Not only are the criteria of division far from specific, but also the categorization - displayed in a table (2007:39) - is rather controversial: it remains unclear why live reporting of a football game on the radio should be more "inspired" than dubbing or subtitling a film, both of which are categorized as "conventional", sharing this status not only with interlingual translation, but also with a number of processes which exemplify a mere transcoding (e.g. transcription between various alphabets in the framework of intralingual translation, or musical notation). Moreover, the mutual translatability of music and visual arts has not been substantiated or exemplified in Gottlieb's paper.

To go back to the issue of the capacity of the notion under discussion, like Michał Pawica (1996), Harish Trivedi (2005/2007), or Edward Balcerzan (2011: 303-309), I am distrustful of catachrestic uses of the term "translation" with reference to phenomena which are not translations. And I do not mean metaphorical uses or ones which relate to, say, translation as "transferring", but academic utterances concerning translation as the subject of translation studies. In this context, it is symptomatic that Henry G. Schogt dissociates himself from the "loose usage" of this notion with reference to "translating" the artist's feelings and experience into an artistic message (1986: 1107, in the article preceding Toury's considerations cited above). Meanwhile, Jakobson's synonym "transmutation" provokes even translation (!) scholars to call such phenomena as "transmigration of souls (including gender transformations)" (Pánková and Beebee 2013, n. pag.), among others, instances of intersemiotic translation. But then - to go back to the definition - translation consists in interpreting signs by means of other signs; consequently, it must occur between semiotic systems. Therefore, such phenomena as "migrancy, exile or diaspora", are not translations, as justly pointed out by Trivedi (2005/2007: 285), even though they may well put the experiencing subject in situations requiring translation.

Therefore, the broadening of the understanding of intersemiotic translation - which will doubtlessly continue, in order to cover new translation activities and new or re-discovered fields of academic interest - should only include such phenomena as occur between semiotic systems. If everything "translates" into everything else, the concept becomes so blurred that it loses its methodological applicability. "Everything is translation"? - beautiful as a metaphor, ineffective as an analytical tool. 


\section{Factors Complicating the Semiotic Status of a Work. Intertextuality}

Discussing and typologizing the phenomenon of transmutation is complicated by a number of factors, which influence the semiotic and semantic complexity of works and of their transformations. For instance, focusing on the creative process, rather than on the final work, can lead to perceiving a multicode work, like a film or a comic book, as a product of a sui generis translation in the sense of executing a script (cf. e.g. Gonçalves de Assis 2015: 251-252). ${ }^{6}$

A studied work may also result from an operation consisting of several stages. For example, the animated film Dante's Inferno, directed by Victor Cook and others, was made on the basis of Jonathan Night's computer game, losing on the way any closer affinity with The Divine Comedy. ${ }^{7}$ Not infrequently, intersemiotic translation relies on interlingual mediation - among the examples cited above this is illustrated by Dziewczyny $z$ kalendarza, a Polish theatrical performance based on an English-language film, or by The Exterminating Angel, with an English libretto despite its Spanish origin. To interpret both situations, it may prove helpful to employ an element of the conceptual framework devised by Carlo Testa for film adaptations or, in this author's terminology, for re-creations (2002: 4-13 and passim). Among other types, Testa distinguishes mediated re-creations, i.e. ones filtered through "an intermediate epiphany" of other works (2002: 18, 123-158). It is striking that in this context the scholar does not mention interlingual translations at all, despite the fact that he is studying the relations of Italian cinema with European literature written in various languages (from Stendhal to Tolstoy). For him, Francesco Rosi's film Carmen (1984), for example, is a mediated re-creation not because of the complexity of its cultural chain (Testa 2002: 135), but because the transformation relies on an earlier operatic transposition by Georges Bizet (Testa 2002: 19, the analysis of the film: 125-142).8

${ }^{6}$ In line with the perspective adopted here, I essentially treat such creations as multicode works. Toury, after all, stresses that the products of processes of a translational character are not necessarily translations themselves (Toury 1986: 1111).

7 A fitting description for it seems to be the phrase coined by Katarzyna Lukas in view of typological difficulties: "a hybrid paratranslational creation" (Lukas 2013: n. pag.) (hybrydyczny twór paratranslacyjny).

${ }^{8}$ Inconsistencies of this classification are perceptible as well when the label of mediated re-creation is also assigned to Nanni Moretti's Palombella rossa (1989), a film realizing Moretti's original script which only quotes David Lean's Doctor Zhivago based on Boris Pasternak's novel (Testa 2002: 18-19, discussion: 143-158). 
There is a further factor that complicates any typology, namely references to other works, pertaining to the same or to another semiotic system. When a verbal text refers to another one, this is normally classified as intertextuality, even if the relation encompasses the text in its entirety, as is the case with a travesty or parody. Thus, Tom Stoppard's play Rosencrantz and Guildenstern Are Dead is not perceived as a "translation" of Shakespeare's Hamlet. If so, the conclusion should naturally extend to, say, a poem which takes as its subject a painting: intermedial allusions give it a referential but not a translational character.

In view of the existing, well-established terminology there is no need to call, for instance, William Carlos Williams' "Landscape with the Fall of Icarus" a "transmutation" of Brueghel's painting (although the definition with no restriction on the direction makes such an approach possible). Some scholars argue, however, that employing the concept of "intersemiotic translation" instead of "ekphrasis" is more effective analytically and offers broader interpretative possibilities (cf. Wysłouch 2007: 503). Yet the limited applicability of such a move becomes apparent in the case of texts referring to several art objects at once, like Auden's "Musée des Beaux Arts" - it is the category of intertextuality that comes to the fore then (I will return to this issue, also in the context of Testa's typology). Moreover, there exist fictitious ekphrases, which could not be called translations for lack of "originals" (certainly, there is a parallel to them in translation studies in the concept of "pseudotranslations", nonetheless, in both cases we are dealing with mystification). Finally, while a specification of an object in a museum's collection might be a pure "transposition" from the visual code into verbal signs, ${ }^{9}$ literary texts will take works of art as a starting point for reflection and not aim at (re)presenting the source. That is why interpreting ekphrases in a translational paradigm can lead to paradoxes, as when Claus Clüver diagnoses a poem as a transmutation on the basis of... divergences from the source work (1989: 71); consequently, what he takes as an indicator of translational nature is a criterion evidently at odds with the commonsensical understanding of translation.

Furthermore, intrasystemic phenomena, such as musical quotations in music or painterly references in paintings, also alert one to the difference between intertextuality and translation. Let me name, e.g., Rachmaninoff's Rhapsody on a Theme of Paganini, op. 43, Marcel Duchamp's L.H.O.O.Q. (reproductions of a moustached and bearded Mona Lisa, a series initiated in 1919), or Raymond Gosin's geometric "remembrances" from the history

${ }^{9}$ Nonetheless, even they are usually more than that, as stressed in the context of translation by Teresa Bałuk-Ulewiczowa (2004). 
of art titled Me Moirs (2012). They are instances of various relations of an allusive nature occurring between works belonging to the same semiotic system. RobertStam, Robert Burgoyne and Sandy Flitterman-Lewis deploy precisely the category of intertextuality (together with transtextuality) to characterize the referential and self-referential practices in cinema (2005: 207-215), while the discourses of the particular disciplines have embraced labels such as "intermusicality", or "intervisuality". At the same time, Toury's typology offers a possibility to classify such works "of second degree" as intrasemiotic translations $^{10}$ - at this point a question arises about the boundary dividing the act of quoting within the same sign system from intrasemiotic translation. The issue of intertextuality will be revisited in a further section of the paper.

\section{(Inter)Semiotic Complementation}

Furthermore, there are phenomena which do not fit Jakobson's definition of transmutation since they imply adding a new code to an existing work instead of changing its code. Consequently, composing music for a poem to form a song is not an intersemiotic translation but rather a semiotic complementation. For instance, when the melody composed by Michael Kamen is added to the pre-existing text of William Shakespeare's sonnet, the two layers together form a new bi-semiotic entity, which in itself is not of a translational nature.

Admittedly, in After Babel George Steiner analyses six musical versions (by five composers) of Margarethe's song from Faust as if they were translations (1975/1998: 419-423). However, he makes beforehand a distinction analogous to what I propose here: between transmutation and combination (1975/1998: 415) $\cdot{ }^{11} \mathrm{~A}$ composer's work in creating a score that would achieve "equity" with respect to the lyrics (1975/1998: 422) is an act of intersemiotic translation, because it is essentially the same as a transposition into purely instrumental music (and Steiner draws interesting analogies with translation proper $^{12}$ ). Even if one agrees with

${ }^{10}$ For instance, George Steiner apparently treats in that way Chaim Soutine's The Skate, which repeats the composition of Chardine's still life of the same title (Steiner 1975/1998: 484).

${ }^{11}$ Although he calls "possibly a twofold translation" a work where music was set to a translated text (Steiner 1975/1998: 419).

12 Trust, appropriation, incorporation and restitution as phases of both processes; the means available to a composer (key, rhythm, instrumentation) correspond to means 
Steiner that the process is (or rather: sometimes is) a translation, still, the result of this process is not: the "translated" music complements the text and a new bi-semiotic text/work emerges. The product is of the same nature as when a work is from the outset created as consisting of more than one layer: an (original) song, opera, comic book, etc. The difference between translation and complementation can be represented in the following scheme:

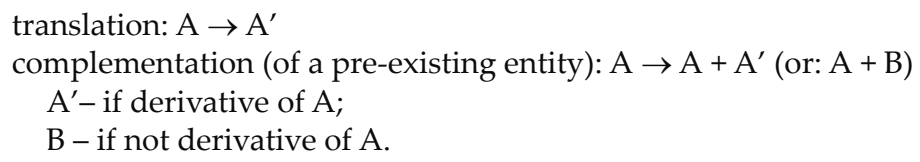

The non-translational nature of the act of adding music is also demonstrated by unsuccessful musicalizations. Anna Barańczak points to cases of infelicitous combinations of music with a pre-existing text, e.g. two settings to poems by Cyprian Kamil Norwid - "W Weronie" set by Andrzej Kurylewicz, and "Bema pamięci żałobny rapsod" set by Czesław Niemen (Barańczak 1983: 42, 141). Although the author does not employ such terms, it follows from her argumentation that the failure of these compositions consists precisely in the fact that the composers did not "translate" the verbal layer. On the other hand, the continued presence of these songs in Polish culture proves that they were not obliged to do so: the melodic lines unquestionably remain in a relation with the poetic texts as their (inter)semiotic complementations. Neither does Erik Redling employ the notion of translation in the part of his article concerned with creating songs by setting poems to music (2015: 419-422).

By the same token, illustrations accompanying a text do not constitute - at least not by definition - its transmutation, but its complementation. To be precise: a specific illustration, or a graphic work, may be an intersemiotic translation of some episode or of condensed features or elements of a verbal text. Nonetheless, illustrating as an activity is not of a translational nature and illustrations are not translations in their essence or generically. I here take a stand against the outlook presented by Katarzyna Lukas: "A typical case of intersemiotic translation is an illustration in a literary work" (2013, n. pag.; trans. mine - M.K.). I renew the reservation made with reference to Steiner's examples - there are

available to a translator; a series of compositions to the same text - a translation series of the same source text; the necessity to choose the tradition according to which one interprets/ composes; the risk of misreading the "original"; the text being possibly manipulated; "improving" on the original; a great setting means an added value, as an outstanding translation does (Steiner 1975/1998: 416-418). 
some musicalizations and some illustrations which strive to "translate" the verbal text, yet neither composing (musical setting) nor illustrating is a creative act of a translational nature. Let us take illustrations as an exemplary phenomenon; that is to say, the reflections presented below can be extrapolated to analogous forms of complementation. Arguments to be substantiated and developed will be grounded in the following premises:

1. Illustrations - in principle - do not function separately (they are meant to coexist with the text, not to represent it).

2. Illustrations do not replace the text.

3. Illustrations are not subject to the requirement of equivalence.

4. Their relation with the text is not necessarily a unique one.

As can be seen, to test the nature of illustrations I intend to refer to some features which are typically attributed to translation and best epitomized by the interlingual one, i.e. "translation proper".

Ad. 1. One of translation's characteristics is that it represents its original for the target recipients, and this function (cf. Popovič 2009: 104) lends it autonomy in the new, foreign context. By and large, translations of texts are printed and read on their own (bilingual editions constitute the exception, not the rule, and are not targeted at a prototypical, i.e. monolingual, recipient of translations). By contrast, illustrations are in principle meant to appear together with the text. This can be substantiated by dictionary definitions in various languages:

Ilustracja - reprodukcja fotografii, rysunku, dzieła malarskiego itp. dodana do tekstu, stanowiąca jego objaśnienie, uzupełnienie i ozdobę; rycina (Szymczak 2002).

['Illustration - a reproduction of a photograph, drawing, painterly work, etc. added to a text, constituting an explanation, supplementation and embellishment for it; a print'; trans. mine - M.K.].

Illustration - pictorial matter used to explain or decorate a text (Anderson et al. 2004).

Illustration - a picture or diagram that is used for clarifying or decorating a text, book, lecture, etc.; illustrate - [...] from Latin illustrare, illustratum 'to light up' (Robinson and Davidson 1996).

Illustration - a picture or drawing or diagram or some other sensory aid that helps make something (a book, a lecture), clear or more helpful or attractive (Webster 1993).

Illustration - action d'illustrer, d'orner d'images [...]. Ensamble des dessins et des gravures figurant dans un ouvrage, pour en augmenter l'attrait ou pour concrétiser des explications [...]. La "gravure d'illustration», insérée dans un texte, s'oppose à l'«estampe», qui est indépendante du livre (Larousse 1962). 
What follows from these is that an illustration does have a certain function with respect to its text, but it is not to represent it. Illustration is something added (cf. Szymczak 2002), inserted (Larousse 1962), external in relation to the text. Characteristically, in Gérard Genette's classification of transcending relations, illustrations have been placed among paratexts (1982: 9). Admittedly, illustrations may be reprinted or exhibited separately, but then, firstly, they are taken out of their primary context and secondly, their status is changed: they are treated as independent works of art, exempt from the illustrating function, a distinction made clear in the French definition. Bibliologists, too, draw attention to that; to cite Janina Wiercińska: one can talk of an illustration "when and only when it appears concurrently with a written or printed text and accompanies this text" (1986: 37, trans. mine - M.K.). Crucially for the present considerations, in the context of intersemiotic translation this co-occurrence of illustration and text is noted by Clüver (1989: $57,78)$.

Ad. 2. In the target culture translation replaces the original (Toury 1986: 1112); in the most basic sense an English rendition of Cervantes, Thomas Mann or Adam Mickiewicz substitutes for the English audience the Spanish, German or Polish original. Is it so with intersemiotic translations? Occasionally it is (although e.g. Clüver assumes the reverse, 1989: 76): realistically speaking, for many recipients a film adaptation does replace the novel in familiarizing them with a given work. ${ }^{13}$ On the contrary, if a foreigner with no command of Polish is presented with an original edition of Adam Mickiewicz's Pan Tadeusz, however richly illustrated, for instance with all sixty classic engravings by Michał Elwiro Andriolli, the graphic material will hardly substitute for him the inaccessible text (an illiterate native speaker of Polish would be in the same position; cf. Fig. 1). And in the illustrator's intention the visual component was not meant to function as such a replacement, in which it differs from visual cycles created with precisely such an objective. The said contrast to illustrations can be found in Biblia pauperum ${ }^{14}$ as well as in modern comics, and the distinction - intuitively perceptible, I believe - consists in narrativity (cf. Szyłak 1999: 26), which characterises illustrations (even their cycles) only to a limited extent. Symptomatically,

${ }^{13}$ Cf. a dialogue in The Master and Margarita, symptomatic for modern culture: "Forgive me, however, perhaps you've never even heard the opera Faust?". The question about the possible familiarity with Goethe's drama, i.e. the source, has been a priori excluded as futile (Bulgakov 1997/2008: 147).

${ }^{14}$ Clüver justly observes, however, that for illiterate recipients its contents became intelligible only thanks to oral verbal commentaries (1989: 57). 
it is precisely with reference to this criterion that theoreticians of film adaptation, like Brian McFarlane, construct their understanding of the relations between literature (usually novels) and cinema. According to McFarlane, what belongs to the narrative can be transferred, what pertains to enunciation requires adapting in the process of creating a film version (1996: 23-30).

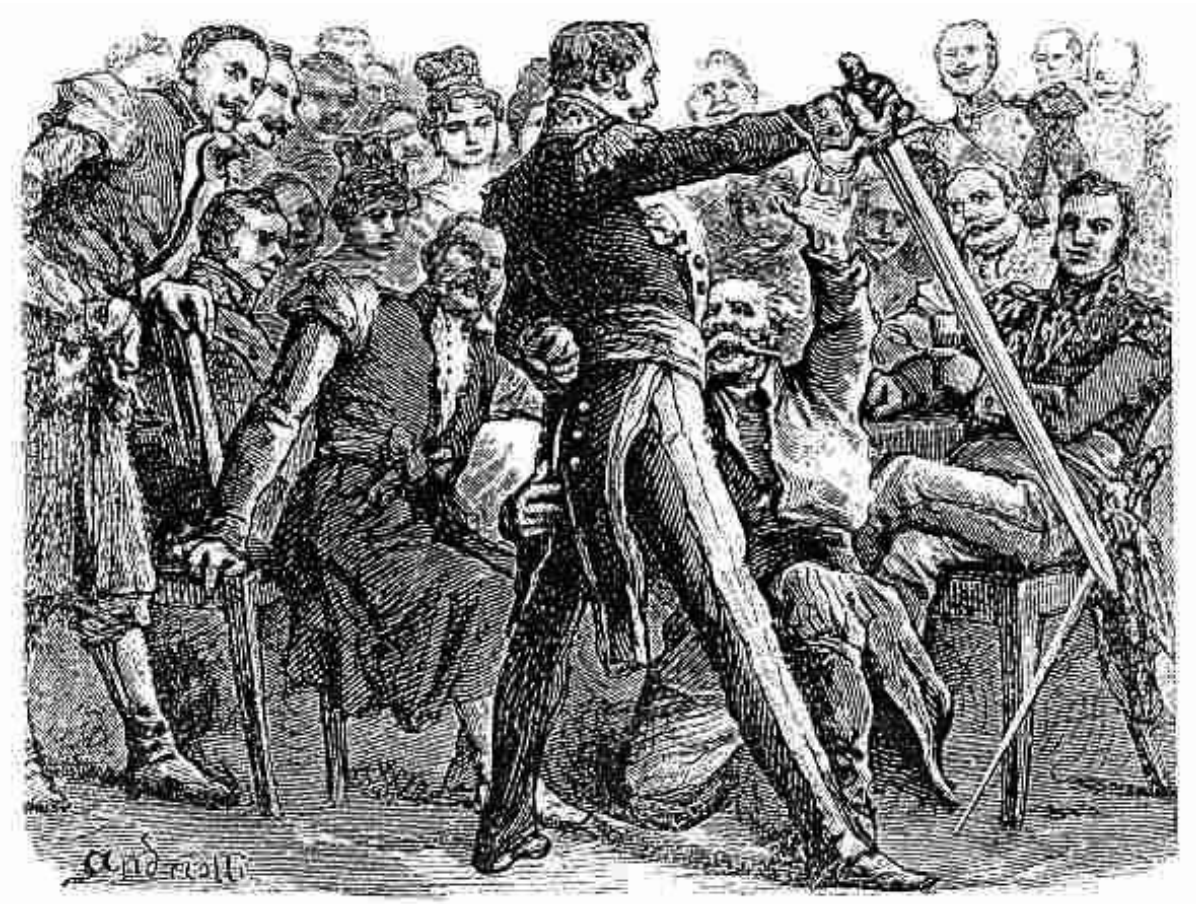

Figure 1. Michał Elwiro Andriolli, Pan Tadeusz, Book 12, engraving 1 (cf. Andriolli 1955)

Ad. 3. Prototypically, translation is defined by notions such as equivalence, adequacy, faithfulness of some sort, however distrustful towards the concept(s) scholars may have become. For the sake of the present verification, let me assume that translation is a creation expected to be equivalent. ${ }^{15}$ Such an assumption has also been made with respect

${ }^{15}$ One could contend that intersemiotic translation is in principle a "free" one and any equivalence between, e.g., music and painting can only be purely conventional. Yet there is a range of arguments against this claim. First and foremost, it undermines the very concept of transmutation as a type of translation; it would mean subscribing to Émile Benveniste's view that signs pertaining to various semiotic systems are not mutually convertible and that between the systems only a certain homology may obtain, and an arbitrary one at that (1969: 9). Secondly, and contrary to Benveniste's statements, George Steiner (in the fragment of After Babel already referred to) so as to have the right to treat 
to transmutation, e.g. Maryla Hopfinger clearly appeals to the criteria of adequacy when defining film adaptation "as transposing the meanings of a message formulated in one semiotic system in such a way as to achieve a message whose senses will be concurrent with the senses of the translated [source] message, thanks to selecting the most appropriate signs from another sign system and the most suitable combination thereof" (1974: 21, trans. mine - M.K.). ${ }^{16}$

As for illustration, it may be abstract or it may not derive from the text in any way. It can be inserted into a publication for embellishment, or even arbitrarily. Take the poem La Prose du Transsibérien et de la Petite Jehanne de France by Blaise Cendrars, originally (in 1913) published with stencil prints by Sonia Delaunay-Terk. It is, arguably, the first book in which the text and the visual layer play equally important parts (Markowski 2007: 314). Delaunay's abstract compositions by no means "translate" the poem, nor the other way round. Autonomous contributions in their own right, the layers complement each other.

True enough, in children's literature an illustration is expected to be suited to the words which it accompanies (cf. e.g. Adamczyk-Garbowska 1988: 159; Oittinen 2000:100-114; Liseling Nilsson 2012: 233): the appearance of the characters should comply with that given in the descriptive passages of the text, there should not be any elements contradicting the verbal layer (e.g. anachronistic). Nonetheless, Joseph H. Schwarcz names as the possible relations between text and illustrations in this genre both congruence (with possible reduction, elaboration, complementation) and deviation - the aim of which may be to counterpoint the words (1982: 14-18). ${ }^{17}$ Thus, even in

musicalizations as translations, indeed looks for adequacy between Goethe's words and the musical means employed by the composers: in terms of tone, formal composition, orchestration, etc. (1975/1998: 419-423). Thirdly, a transmutation which strikes the recipients as inadequate with respect to the original, may be - and more often than not is - perceived as a failed translation, not as a non-translation. Film scholars also underscore this: McFarlane, for instance, mentions an inclination of "the general film-viewer" to compare adaptations with their literary sources, "usually to the film's disadvantage" (1996: 23).

${ }^{16}$ There is a vast literature on the subject of the theory of adaptation, including adaptation understood as intersemiotic translation. An overview of it would go beyond the scope and aims of the present paper. Let us just note that e.g. considerations on the background presence of the original are not shunned by Alicja Helman (1979) and also Patrick Cattrysse, who locates his research in polysystem studies, employs the notions of invariance and equivalence (1992: 54).

17 The interrelations between text and image have been variously classified by, among others, Teresa Tomaszkiewicz (2006: 58-63), Radan Martinec and Andrew Salway (2005), Scott McCloud (1994: 153-155), Andrew Goodwin (1993: 86-88). Presenting these typologies goes beyond the scope of this paper. 
this field, where conformity with the verbal text is a strong theoretical and critical postulate, illustrating can hardly be unequivocally understood as an activity implying equivalence.

Józef Wilkoń, an eminent Polish illustrator, openly distances himself from the concept of illustrating as translating. He stresses that his work is "parallel" to the writer's and likens it to musical accompaniment (Wilkoń 2009-2010: 299), a metaphor clearly concurrent with the concept of complementation proposed here. Although conceding that the task of creating "an adequate illusion" accounts for a certain similarity between an illustrator and a translator (2009-2010: 306), ${ }^{18}$ Wilkoń also postulates that illustrating should not be literal; the closer it clings to the text, the less does an illustration have to say (2009-2010: 297, 299). His emphasis on non-literality strengthens the case for illustrations not being translations.

Ad. 4. Although it is not a feature particularly underscored in the discipline (which pays more attention to the fact that one text may generate multiple renditions), a translation refers back to one source text. Even in the case of textual variants, in a particular place a particular single segment of the original becomes the basis for translation - a segment recognized as canonical, although perhaps collated with several textual variants. There must also be segments of the bi-text corresponding to each other in a linear sequence. An illustration, even if related to a particular episode of the verbal layer, can bring together and fuse various elements of its source. It may also be inserted in various places of the edition, which testifies to its weaker relation with the verbal segment to which it owes its origin. Moreover, certain illustrations can equally well illustrate totally different texts - they sometimes even cross national barriers in that: the same prints by Stanisław Wyspiański that had served as vignettes in a turn-of-the- $20^{\text {th }}$-century Polish literary magazine were inserted into a 2006 Russian edition of translations from the Polish modernist poet Bolesław Leśmian (Десьмян 2006: 13, 55, 101, 175, 263; see analysis in: Kaźmierczak 2010: 325-342).

While many an illustration may potentially complement a range of books as a cover, an adapted graphic novel unequivocally refers to a single source text, which attests to the translational character of the relation between the two (compare Fig. 2 and 3).

${ }^{18}$ With this concession Wilkon seems to oblige the interviewer, who has restated her question, first answered negatively (2009-2010: 299). 


\section{Joseph Conrad}

\section{Jądro ciemności}

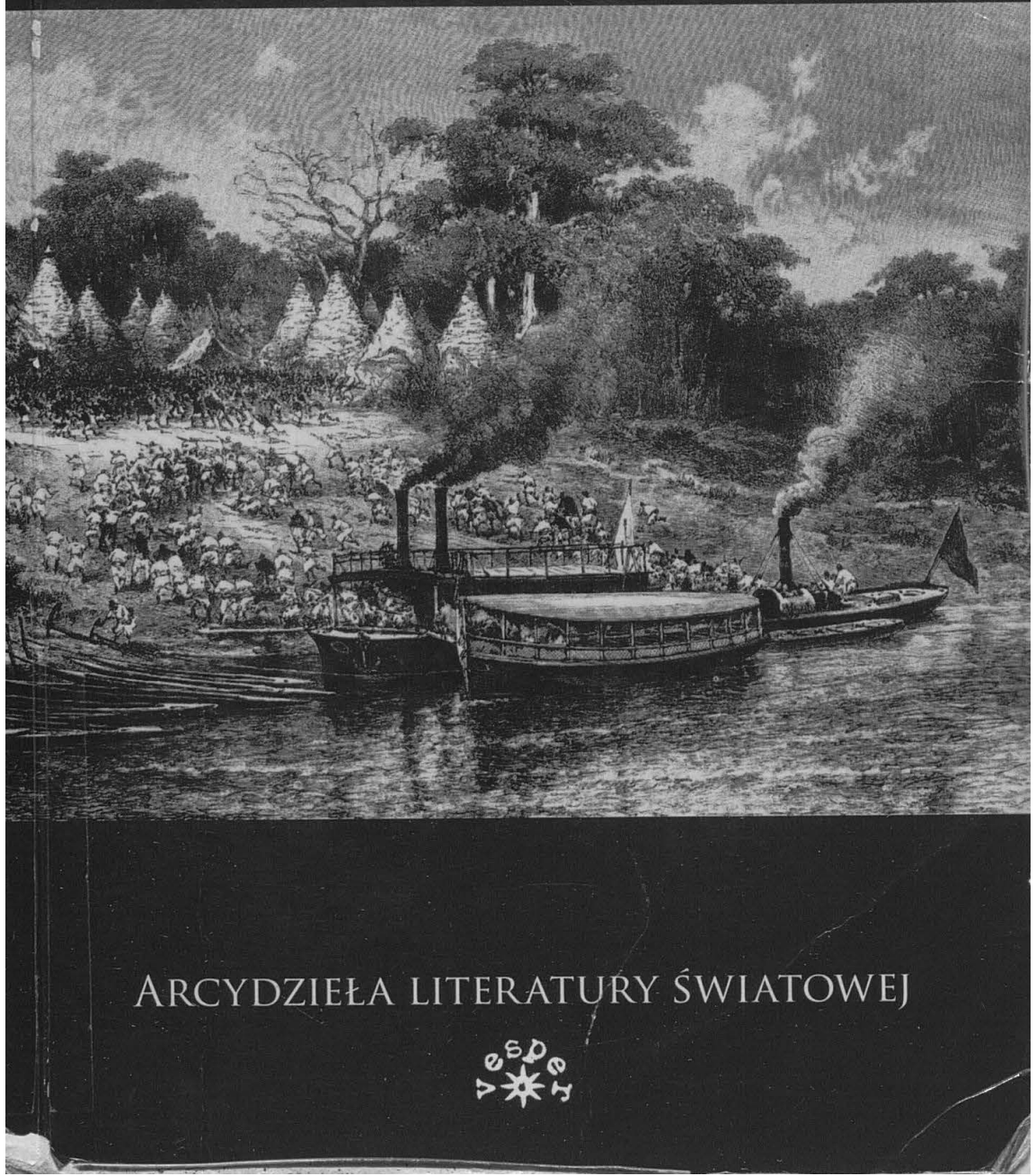

Figure 2. Joseph Conrad, Jąro ciemności, cover; publisher: Vesper (Conrad 2009) 

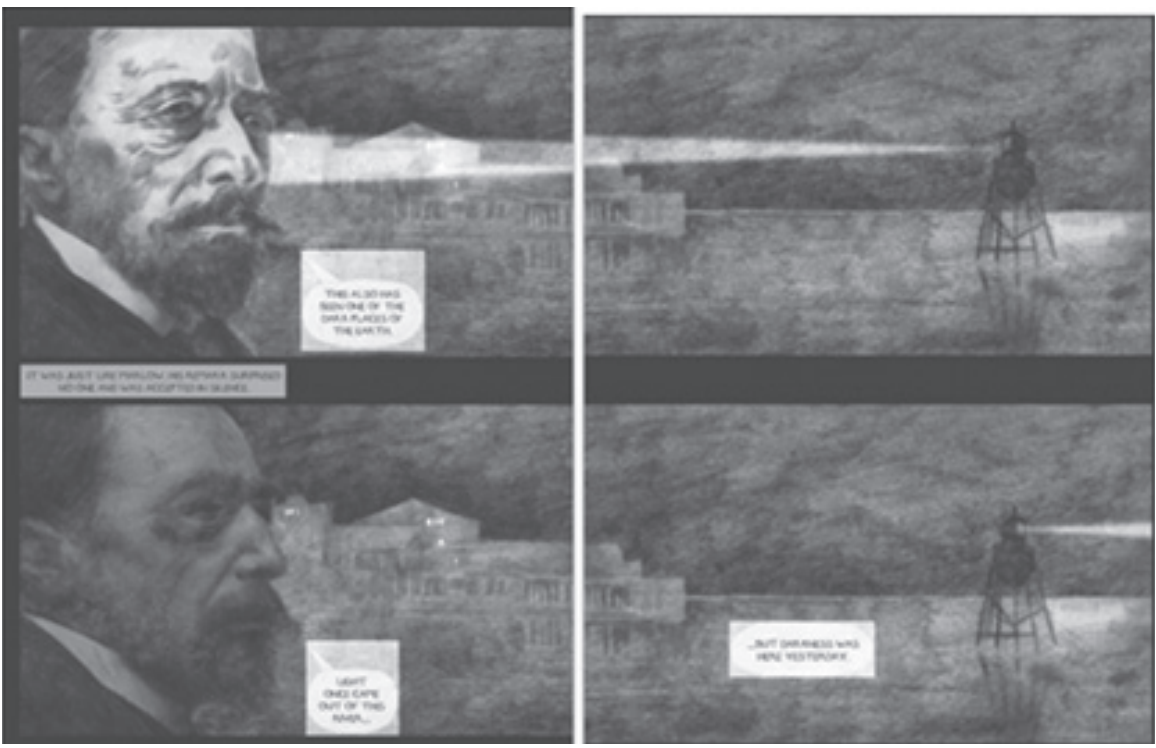

Figure 3. Catherine Anyango, David Zane Mairowitz, Heart of Darkness, a fragment (from: Anyango, Mairowitz 2010)

The cover for a Polish edition of Heart of Darkness (the colophon does not name its designer), and the graphic novel Heart of Darkness by Catherine Anyango and David Zane Mairowitz prove to be, respectively, a complementation and a transmutation of the same text by Joseph Conrad. In turn, an original graphic novel or a comic book also undermine the concept of illustration as translation. The cooperation of artists suggests complementation, whereas when both semiotic channels are created by the same author, probably neither of them is a self-translation.

The uniqueness of the relation could perhaps be challenged as one of the criteria of translational nature, on the ground that in contemporary culture intersemiotic translation often entails merging various texts into one. Indeed, Carlo Testa in his classification of film adaptations includes hypertextual re-creations, i.e. ones which incorporate more than one text by a given author (2002: 19; he applies this framework to, e.g., Visconti's Death in Venice, 2002: 183-201). Such is, in fact, also the case of Anyango and Mairowitz, who have embedded in Heart of Darkness excerpts from Conrad's Congo Diary. A similar example in Polish, equally complex semiotically, is the stage version of Nikolai Gogol's The Overcoat (television productions: 1954, 1973, 1978, 1998) into which its translator-adaptor Julian Tuwim integrated a subplot relating to the play The Government Inspector (here the intersemiotic translation additionally makes use of interlingual mediation). 
Yet principally we are dealing with intertextuality: you know that you are perceiving a graphic version of Heart of Darkness, with overt (Mairowitz signals them in the introduction and the interpolations appear under the header Congo Diary) references to another text; you know that you are watching a theatrical rendition of Gogol's short story, with a certain thread added with a view to activating new allusive meanings. Moreover, even if the sources are plural, the link with them remains a single one-Khlestakov's subplot does not refer to, say, any comedy set in the $19^{\text {th }}$ century Russian back country, but to a specific work. The overt quotations in Anyango and Mairowitz's text have one intertextual address, Congo Diary, whereas the illustration shown for comparison (Fig. 2) potentially connotes any novel whose action takes place on a river, from The African Queen to The Adventures of Huckleberry Finn.

My intention is by no means to negate the importance of studying the ways in which visual arts transpose words, nor to question the significance of enquiry into illustrations for translation studies (see further in the paper). I only argue against taking it for granted that illustrations (or musicalizations) are by definition translations. Even when the graphic layer in microscale is based on a verbal text, in the macroscale many scholars show preference for more guarded terms and for emphasizing interactions. Hence, for instance, Sylvia Liseling Nilsson's "dialogue", derived from Bakhtin's concepts (2012: 227 in the context of illustrations; $41-45$ for the Bakhtinian context of her study) or "visual interpretation" (Imperowicz-Jurczak 2014). I also intend to draw attention to misleading suggestions inherent in terminology like "translating pictures" $(\mathrm{O}$ 'Sullivan 2006) or "graphic translation" (Jankowski 2014), if it is not the image that is subject to translation, but rather the verbal text. To compare, for Liangyu Fu (2013) "translating illustrations" actually means transforming the visuals and Tamara Brzostowska-Tereszkiewicz construes "graphic(al) translation" as replacing verbal text with graphic signs (2016: 170-180).

One more remark in this section, to refute the possible objection that introducing the notion of semiotic complementation complicates rather than facilitates categorizing some phenomena. Audio description, which - in keeping with the consensus in the discipline - has been classified above as an instance of intersemiotic translation, complements other elements of a film, and can be perceived as its semiotic enrichment, as adding another layer to the verbal auditory channel, already comprising the dialogues and possible background voices. Yet, at the same time, audio description is a prototypical case of replacing one semiotic code by another and for this segment of the audience for whom it was devised 
(see Benecke 2004 on this aspect), for the blind, it substitutes one of the channels of the cinematic message - the visual. Other contexts, e.g. its use in museums, demonstrate as well that for the blind, audio description fulfils the function of representing visual art objects, which confirms its translational nature. Therefore, the differentiation between complementation and transmutation helps define with more precision the functions and status of $\mathrm{AD}$, which change depending on the recipients and their needs - those resulting from sensory deprivation but also others: aesthetic or cognitive ones (nowadays AD plays a role in education, in developing cognitive abilities - cf. Krejtz et al. 2012; Gottlieb, in a related case, calls such an intersecting of functions "translation crossover", 2007: 37).

\section{Intersemiotic Aspects of Interlingual Translation}

Unquestionably, intersemiotic translation often coexists and overlaps with interlingual one. Polysemiotic works (some of which may be products of intersemiotic translation) which contain verbal elements are frequently translated into other natural languages. An interlingual translation of a polysemiotic work/text may not be an especially handy term, but it is a precise one. It should not be "cut short" to "intersemiotic translation" when a film, a graphic novel, a computer game, a song, an opera, etc. is translated from language to language. What takes place then is interlingual translation in the process of which it is obligatory to take into account other semiotic codes / layers constituting the work.

Admittedly, these kinds of translation are rather particular and therefore specific names, definitions, and subdisciplines have been developed in many cases: melic ${ }^{19}$ (vocal) translation, audiovisual translation, localization (cf. Tab. 1). However, since some scholars apply the term "intersemiotic translation" to these subtypes, let me explain my claim in more detail.

19 The term "melic translation" has little currency in English; nonetheless, I have decided to use it in keeping with the Polish academic discourse wherein ttumaczenie meliczne refers to the practice of translating a verbal-musical text in such a way that the product can be sung to the original music. It is, therefore, more precise than e.g. "song translation" which does not presuppose any specific approach from the many possible. 
Table 1. Intersemiotic translation vs. NOT intersemiotic translation (but...)

\begin{tabular}{|l|l|}
\hline Intersemiotic translation & NOT intersemiotic translation (but...) \\
\hline graphic novel based on literature & illustrating (complementation) \\
\hline programme music & setting a text to music (complementation) \\
\hline audio description & $\begin{array}{l}\text { translating a song, an opera (melic } \\
\text { translation) }\end{array}$ \\
\hline film adaptation & translating a film script (AVT) \\
\hline $\begin{array}{l}\text { computer game based on literature or } \\
\text { film }\end{array}$ & translating a computer game (localizing) \\
\hline
\end{tabular}

Teresa Tomaszkiewicz classifies audiovisual translation (AVT) as "intersemiotic translation" (2006:97-100) but uses thelabel with apparently little conviction (cf. also 2006: 67): she feels obliged to underscore that "the translator's task is only to effect an interlingual transfer", since he or she "cannot interfere with the visual layer" 20 (2006: 97, trans. mine - M.K.). The scholar comes to the definition of AVT as "a particular type of translation that combines elements of classic interlingual translation and intersemiotic translation" (2006: 100, trans. mine - M.K.). Yet this is contrary to the essential idea of transmutation, since no change of semiotic form occurs. A film translated from language A into language B continues to be a film, it remains in the same semiotic system (exactly like a remake in relation to its screen original). Even conceptualizing this operation as a "transfer between two semiological complexes", as Tomaszkiewicz justly postulates (2006: 100), does not remove its fundamental incompatibility with the definition of intersemiotic translation by Jakobson and by Toury, with the requirement of code change. As Aline Remael observes, "in multimedia translation, we are not really dealing with intersemiotic translation, i.e., translation from one semiotic system to another, but with the translation of texts and intertextuality" (2001: 13-14).

To move to a different field, a graphic novel based on Heart of Darkness is an intersemiotic translation, whereas rendering such a graphic novel from English into other natural languages is not. Renditions of Anyango and Mairowitz's work will be interlingual translations which should account for the intersemiotic context, i.e., for the coexistence of the layers constituting the text. Such an operation may, paradoxically, acquire traits of intralingual translation, if an existing target-language rendition of Conrad's novella is used (note the same name of the translator in the case of the Dutch versions of both texts: Anyango, Mairowitz 2011 and Conrad

${ }^{20}$ This premise is not universally accepted, see also remarks on the graphic intervention in the next paragraph of the present paper. 
1994; the Polish rendition of the graphic novel was published by Magda Heydel who had translated Conrad - cf. Anyango, Mairowitz 2017 and Conrad 2011 21 . Nowadays intervention in the visual channel in foreign editions is already possible. Tilmann Altenberg and Ruth J. Owen state that translating comics may entail both rewriting the text and redrawing the image, combined in varied proportions (2015: 1). Still, graphic intervention is applied to a limited extent, ${ }^{22}$ the more so since redrawing "goes against [the] foundations of authorship, meaning and aesthetics" (Gonçalves de Assis 2015: 253). In the case considered here, a systematic replacement would not only efface the relation with Anyango's work, but also remain... an intrasemiotic transformation..$^{23}$

A similar restriction should be imposed on terminology relating to the translation of verbal-only works which carry references to nondiscursive media. Rendering from one natural language into another a text containing allusions to cinema or music does involve intersemiotic aspects, yet by no means constitutes an act of intersemiotic translation. The distinction, however, is not always observed. For instance, when discussing the rendering of Jean Tardieu's poem whose topic is the person and art of Henri Rousseau, Małgorzata Zawadzka asks in her title: "How do you translate a painting?" (2009: 213). She concludes: "Because of the continuous necessity to confront the text with paintings, the translator at times has the impression of translating a painting, not a poem. A painting created partly by Henri Rousseau and partly by the poet" (2009: 219; trans. mine - M.K.). The paper focuses on French to Polish translation proper, except in the title and in the final metaphor, and it is in this frame that the concept of intersemiotic translation becomes so diluted. The "painting" which the translator has "the impression" of translating does not, in fact, exist, as the addition about the "joint authorship" discloses. The metaphor enters the terminological field here, causing "terminological disturbances", to quote Balcerzan's phrase again.

Far from having the intention of introducing terminology and divisions for their own sake, I believe that making certain distinctions will

${ }^{21}$ For an analysis of the graphic novel as a transmutation, prompted by the appearance of Heydel's rendition, see Jarniewicz 2018.

${ }^{22}$ Elżbieta Skibińska writes about the image as unalterable in foreign-language editions of comic books. She points to certain advantages of this situation - not necessarily taken in publication practice - for intercultural communication (cf. Skibińska 2008: 230-242).

${ }^{23}$ It is precisely as intrasemiotic translation that Rachel Weissbrod and Ayelet Kohn (2015) describe re-illustrating comic books while leaving the verbal text intact (within the same language). Admittedly, there occurs an evident change of aesthetic code - which was the intent of the transformations - but the result of this operation is a semiotic complex of the same kind (translating from comics into comics). 
allow us to see with greater precision what is and what is not an object for translation studies analysis. For instance, what is of (professional) interest to translation scholars is how a song is translated; they are not, strictly speaking, concerned with how a poem becomes a song - unless they compare the two processes as Krystyna Pisarkowa does (1998: 6087 on "Ode to Joy": Schiller - Beethoven - K. I. Gałczyński's singable Polish version; though even here the scholar does not, actually, deal with musicalization but rather with the composer's textual operations). Analogically, painterly transmutations of literature become the object of translatological study only when matched with interlingual translation (e.g. Moriconi 2014 on Dante in Rossetti's twofold renditions). What deserves stressing, though, is that intersemiotic aspects of translation offer a promising and exceptionally rich field of enquiry. Let me enumerate certain issues worth exploring:

- verbal references to other media as a translation problem;

- image as an obstacle and as a facilitation to text translation;

- transfer of illustrations vs. creating new ones in the target culture; such analyses should simultaneously take the verbal text into account; ${ }^{24}$

- possible influence of the text of translation on illustrations for the foreign edition (cf. Kaźmierczak 2006);

- possible discrepancies between the verbal and the visual channel resulting from translation;

- influence of illustrations on the reception and interpretation of a translated text (cf. Teodorowicz-Hellman 1995);

- illustrations as a source of knowledge about the original culture; the truthfulness of the information (cf. Liseling Nilsson 2012: 237-278); the explanatory potential of the visual material in foreign editions (cf. Lukas 2013 concerning German editions of Mickiewicz's Pan Tadeusz in that respect);

- melic aspects of the translation of musical-verbal texts;

- typographic aspects of translation (cf. Kaźmierczak 2015; Schultze 2016);

- reception of transmutations as paving way for the interlingual translation of the source work: e.g. an AVT of a film preceding the translation of the underlying novel (a trend of translating into Japanese Western books which had been filmed is mentioned by Masaomi Kondo and Judy Wakabayashi [1998: 491]);

${ }^{24}$ It is worth noting that Liangyu Fu's interesting paper (2013) on translating illustrations is insufficient in this aspect: it omits the textual contexts in which the prints under discussion are embedded. 
- an interlingual translation's potential to generate semiotic complementations (cf. Barańczak 2004:342 where the declared translation objective and the aim of particular metrical choices is to "open the way for new melodies to which this text can be set"; trans. mine-M.K.) and transmutations in the target culture;

- instances of suppressed mediation of interlingual translation in the process of transmutation (e.g. Leonard Bernstein's Serenade after Plato's Symposium, 1954, instrumental; the composer's synopsis does not name the variant of the text - presumably a translational one - which inspired it; Bernstein 1998: 6-7).

\section{Conclusion}

Having drawn the map of intersemiotic aspects of translation, I would like to recapitulate the key points of the present argumentation.

In whatever ways we broaden the understanding of the notion introduced by Jakobson as intersemiotic translation, its application should be restricted to transpositions from one sign (semiotic) system to another. Consequently, if intersemioticity is understood as all sorts of reference of a verbal text to non-discursive media and arts, then translation of works containing such references should not be called intersemiotic translation, since no change of code occurs; neither does it take place in audiovisual translation (translating a poem into a poem, film into a film, etc., does not have intersemiotic character).

Secondly, the scope of the term should be limited to phenomena which are of a translational nature. Semiotic transformations which entail adding a new code to an existing work, rather than changing its code, do not actually fit Jakobson's definition and, in view of this, the notion of (inter)semiotic complementation has been proposed here.

In turn, translating between natural languages a polysemiotic work, or a verbal text which refers to non-discursive media, constitutes an interlingual transfer accommodating intersemiotic aspects and should be studied from precisely such a perspective.

I believe that the proposed differentiation between intersemiotic translation as such, intersemiotic complementation of an existing work and intersemiotic aspects of interlingual translation can contribute to the clarity of defining research objectives. If the distinction is adopted, it becomes apparent that what is relevant for the discipline of translation studies is not intersemiotic translation in itself but its implications for interlingual 
translation: (1) translating poems, graphic novels, films, operas, etc. in a way which accommodates their inter- or polysemiotic nature and intersemiotic contexts; (2) taking into consideration intersemiotic aspects when studying such renditions. The difference perhaps accounts for the scarcity of translation studies research on transmutation underscored by Mona Baker and Teresa Tomaszkiewicz.

\section{References}

Adamczyk-Garbowska, Monika (1988). Polskie ttumaczenia angielskiej literatury dziecięcej. Problemy krytyki przekładu. Wrocław: Ossolineum.

Altenberg, Tilmann, Ruth J. Owen (2015). "Comics and Translation: Introduction". New Readings 15: i-iv. Eds. Tilmann Altenberg, Ruth J. Owen.

Anderson, Sandra, et al. (eds.) (2004). Collins English Dictionary. $8^{\text {th }}$ edition. Glasgow: Harper Collins.

Andriolli, Michał Elwiro (1955). Ilustracje do "Pana Tadeusza", engravings. Warszawa: Wydawnictwo Sztuka.

Anyango, Catherine, David Zane Mairowitz (2010). Heart of Darkness. Adapted from the original novel by Joseph Conrad. London: SelfMadeHero.

Anyango, Catherine, David Zane Mairowitz (2011). Hart der duisternis. Naar de roman van Joseph Conrad, trans. Bas Heijne. Amsterdam: Atlas.

Anyango, Catherine, David Zane Mairowitz (2017). Jadro ciemności. Powieść graficzna, na podstawie powieści Josepha Conrada. Trans. Magda Heydel in collaboration with Wanda Heydel. Kraków: Lokator.

Baker, Mona (1998). "Introduction". In: Routledge Encyclopedia of Translation Studies. Eds. Mona Baker, Kirsten Malmkjær. (xiii-xviii). London: Routledge.

Balcerzan, Edward (2011). Tłumaczenie jako "wojna światów". W kręgu translatologii $i$ komparatystyki. $3^{\text {rd }}$ ed. Poznań: Wydawnictwo Naukowe UAM.

Bałuk-Ulewiczowa, Teresa (2004). "Values in the Visual Arts and Untranslatability. Powerless Pastors-Faithful and Wolves in Sheep's Clothing". In: Przekładajac nieprzektadalne. Eds. Olga Kubińska, Wojciech Kubiński. Vol. 2. (101-108). Gdańsk: Wydawnictwo Uniwersytetu Gdańskiego.

Barańczak, Anna (1983). Stowo w piosence. Poetyka wspótczesnej piosenki estradowej. Wrocław: Ossolineum-PAN.

Barańczak, Stanisław (2004). "Mała antologia przekładów-problemów...: William Shakespeare, 'It was a lover and his lass"'. In: Stanisław Barańczak, Ocalone w tlumaczeniu. $3^{\text {rd }}$ ed. (341-342, 457). Kraków: a5.

Benecke, Bernd (2004). "Audio-Description". Meta 49 (1): 78-80.

Benveniste, Émile (1969). "Sémiologie de la langue" (1). Semiotica 1 (1) : 1-12.

Bernstein, Leonard (1998). Serenade after Plato's Symposium (from original LP notes). In: Bernstein Century: Prelude, Fugue and Riffs [and other compositions]. Sony Classical: 6-7. CD sleeve note. 
Brzostowska-Tereszkiewicz, Tamara (2016). Modernist Translation. An Eastern European Perspective. Models, Semantics, Functions. Frankfurt am Main: Peter Lang.

Bulgakov, Mikhail (1997/2008). The Master and Margarita. Trans. Richard Pevear, Larissa Volokhonsky. E-book [originally: Harmondsworth: Penguin].

Cattrysse, Patrick (1992). "Film (Adaptation) as Translation: Some Methodological Proposals". Target 4 (1): 53-70.

Cendrars, Blaise, Sonia Delaunay (1913/2008). La Prose du Transsibérien et de la Petite Jehanne de France. Ed. T. Young. New Haven: Beinecke Rare Book and Manuscript Library Yale University Press.

Clüver, Claus (1989). “On Intersemiotic Transposition”. Poetics Today 1 (10): 55-90.

Conrad, Joseph (1994). Hart der duisternis. Trans. Bas Heijne. Amsterdam: Veen.

Conrad, Joseph (2009). Jądro ciemności. Trans. Jędrzej Polak. Poznań: Vesper.

Conrad, Joseph (2011). Jądro ciemności. Trans. Magda Heydel. Kraków: Znak.

Del Grosso, Simone (2008). Sequenze. Strategie e dispositivi di traduzione intersemiotica dal romanzo inglese al cinema. Roma: Aracne.

Díaz Cintas, Jorge (2005). "Audiovisual Translation Today. A Question of Accessibility for All". Translating Today 4: 3-5.

Díaz Cintas, Jorge, Lucile Desblache (2007). "Accessibility and/in Translator Training", paper read at $5^{\text {th }}$ EST Congress Why Translation Studies Matters. University of Ljubljana, Slovenia, 3-5 Sept. 2007.

Eco, Umberto (2000). “Traduzione e interpretazione”. Versus 85-86-87: 55-100.

Fu, Liangyu (2013). "Indigenizing Visualized Knowledge: Translating Western Science Illustrations in China, 1870-1910". Translation Studies 6 (1): 78-102.

Genette, Gérard (1982). Palimpsestes. La littérature au second degré. Paris: Seuil.

Gogol, Mikołaj (1998). Płaszcz. Adapt. Julian Tuwim, dir. Andrzej Domalik. TVP [Polish Television].

Gonçalves de Assis, Érico (2015). “The Letterer as a Translator in Comics Translation”. In: Comics - Übersetzungen und Adaptionen. Ed. Nathalie Mälzer. (251-267). Berlin: Frank \& Timme.

Goodwin, Andrew (1993). Dancing in the Distraction Factory: Music Television and Popular Culture. London-New York: Routledge.

Gottlieb, Henrik (2007). "Multidimensional Translation: Semantics Turned Semiotics”. In: Challenges of Multidimensional Translation. Eds. Sandra Nauert, Heidrun Gerzymisch-Arbogast. Proceedings of the Marie Curie Euroconferences MuTra 2005. (33-61). Saarbrücken: Saarland University.

Helman, Alicja (1979). "Modele adaptacji filmowej. Próba wprowadzenia w problematykę". Kino 6: 28-30.

Hopfinger, Maryla (1974). Adaptacje filmowe utworów literackich. Problemy teorii i interpretacji. Wrocław: Ossolineum.

Imperowicz-Jurczak, Małgorzata (2014). “Bene nati w interpretacji plastycznej Piotra Stachiewicza". Przestrzenie Teorii 22: 71-87.

Jakobson, Roman (1959/2000). “On Linguistic Aspects of Translation”. In: The Translation Studies Reader. Ed. Lawrence Venuti. (113-118). London: Routledge. 
Jakobson, Roman (1971). "Language in Relation to Other Communication Systems". In: Roman Jakobson, Selected Writings. Vol. I: Word and Language. (697-708). The Hague-Paris: Mouton.

Jankowski, Jakub (2014). “O przekładzie komiksu, czyli uwagi teoretycznopraktyczne o tłumaczeniu graficznym". Między Oryginałem a Przekładem 3 (25) (vol. XX): 67-85.

Jarniewicz, Jerzy (2018). “To See Heart of Darkness. On the Intersemiotic Translation of Joseph Conrad's Novel". Trans. Zofia Ziemann. Przekładaniec. A Journal of Translation Studies. Special issue: Word and Image Translation [English of vols 34-35]: 36-51.

Kaźmierczak, Marta (2006). “Leśmian po rosyjsku ilustrowany przez Alinę Golachowską". In: Dialog czy nieporozumienie? Z zagadnień krytyki przekładu. Eds. Piotr Fast, Przemysław Janikowski. (63-84). Katowice: "Śląsk".

Kaźmierczak, Marta (2010). Intertekstualne i intersemiotyczne aspekty przekładu poezji Bolesława Leśmiana na języki rosyjski i angielski. PhD dissertation. Łódź: Uniwersytet Łódzki.

Kaźmierczak, Marta (2015). “Typografia a przekład”. In: Sensualność w kulturze polskiej. Przedstawienia zmysłów człowieka w języku, piśmiennictwie i sztuce od średniowiecza do wspótczesności [The Senses in Polish Culture] [Internet thematic encyclopedia]. Ed. Włodzimierz Bolecki. Warszawa: Instytut Badań Literackich PAN. http://sensualnosc.bn.org.pl/pl/articles/typografiaa-przeklad-810/ (accessed May 8, 2017).

Kondo, Masaomi, Judy Wakabayashi (1998). "Japanese Tradition". In: Routledge Encyclopedia of Translation Studies. Eds. Mona Baker, Kirsten Malmkjær. (485494). London: Routledge.

Krejtz, Krzysztof et al. (2012). "Multimodal Learning with Audio Description". In: Proceedings of the ACM Symposium on Applied Perception. (83-90). New York: ACM.

Larousse (1962). Grand Larousse Encyclopédique en dix volumes, tome sixième [vol. 6]). Paris: Librairie Larousse.

Liseling Nilsson, Sylvia A. (2012). Kod kulturowy a przekład. Na podstawie wybranych utworów Astrid Lindgren $i$ ich polskich przekładów. Stockholm: Stockholms universitet.

Lukas, Katarzyna (2013). "Przekład intersemiotyczny". In: Sensualność w kulturze polskiej. Przedstawienia zmysłów człowieka w języku, piśmiennictwie i sztuce od średniowiecza do współczesności [The Senses in Polish Culture] [Internet thematic encyclopedia]. Ed. Włodzimierz Bolecki. Warszawa: Instytut Badań Literackich PAN. http://sensualnosc.bn.org.pl/pl/articles/przeklad-intersemiotyczny-638/ [accessed May 8, 2017].

Markowski, Michał Paweł (2007). Polska literatura nowoczesna. Leśmian, Schulz, Witkacy. Kraków: Universitas.

Martinec, Radan, Andrew Salway (2005). “A System for Image-Text Relations in New (and Old) Media". Visual Communication 4 (3): 337-371.

McCloud, Scott (1994). Understanding Comics: The Invisible Art. New York: Harper Perennial. 
McFarlane, Brian (1996). Novel to Film: An Introduction to the Theory of Adaptation. Oxford: Clarendon Press.

Moriconi, Chiara (2014). “Dante's Dream: Rossetti's Reading of the Vita Nuova Through the Lens of a Double Translation". Nordic Journal of English Studies 13 (4): 56-80.

O'Sullivan, Emer (2006). "Translating Pictures". In: The Translation of Children's Literature: A Reader. Ed. Gillian Lathey. (113-121). Clevedon-Buffalo-Toronto: Multilingual Matters.

Oittinen, Riitta (2000). Translating for Children. New York-London: Garland Publishing. Pánková, Lenka, Thomas O. Beebee (2013). "Dictionary of the Khazars as Translational Fiction". In: Czech, Slovak and Polish Structuralist Traditions in the Translation Studies Paradigm Today. Charles University, Prague, 26-29 Sept. 2013. Conference abstracts (n. pag.).

Pawica, Michał (1996). "Przeciw pantranslatologii albo o tłumaczeniu synowi matematyki i przekładaniu tortu masą". In: Między oryginałem a przekładem. Eds. Maria Filipowicz-Rudek, Jadwiga Konieczna-Twardzikowa. Vol. II: Przekład, jego tworzenie się i wptyw. (399-409). Kraków: Universitas.

Pisarkowa, Krystyna (1998). Pragmatyka przekładu. Przypadki poetyckie. Kraków: IJP PAN.

Popovič, Anton (2009). “Teoria przekładu w systemie nauki o literaturze”. Trans. Maryla Papierz. In: Współczesne teorie przekładu. Antologia. Eds. Piotr Bukowski, Magwda Heydel. (89-106). Kraków: Znak.

Redling, Erik (2015). “The Musicalization of Poetry”. In: The Handbook of Intermediality: Literature - Image - Sound - Music. Ed. Gabriele Rippl. (412-426). Berlin: Mouton de Gruyter.

Remael, Aline (2001). "Some Thoughts on the Study of Multimodal and Multimedia Translation". In: (Multi)Media Translation). Eds. Yves Gambier, Henrik Gottlieb. (13-22). Amsterdam: John Benjamins.

Robinson, Mairi, George Davidson (eds.) (1996). Chambers 21 $1^{\text {st }}$ Century Dictionary. Edinburgh: Chambers.

Schogt, Henry G. (1986). “Translation”. In: Encyclopedic Dictionary of Semiotics. Ed. Thomas A. Sebeok. Vol. 2 (1107-1111). Berlin: Mouton de Gruyter.

Schultze, Brigitte (2016). "Hybridity Maintained, Reduced, Abolished and Redefined: The Czech Graphic Novel Alois Nebel (Jaroslav Rudiš, Jaromir 99, 2006) in Polish and German". Rocznik Komparatystyczny - Comparative Yearbook 7: 41-55.

Schwarcz, Joseph H. (1982). The Ways of the Illustrator. Visual Communication in Children's Literature. Chicago: ALA.

Skibińska, Elżbieta (2008). “Niedoceniona wartość przymusu. O przekładzie pewnego komiksu dla dzieci". In: Elżbieta Skibińska. Kuchnia tłumacza. (230-242). Kraków: Universitas.

Stam, Robert, Robert Burgoyne, Sandy Flitterman-Lewis (2005). New Vocabularies in Film Semiotics. London-New York: Routledge.

Steiner, George (1975/1998). After Babel: Aspects of Language and Translation. $3^{\text {rd }}$ ed. Oxford: Oxford University Press.

Szyłak, Jerzy (1999). Komiks w kulturze ikonicznej XX wieku. Gdańsk: słowo/obraz terytoria. 
Szymczak, Mieczysław (ed.) (2002). Stownikjęzyka polskiego. Warszawa: Wydawnictwo Naukowe PWN.

Teodorowicz-Hellman, Ewa (1995). "Nils Holgerssons resa över Polen: En analys av läsprocessen". Slovo: Journal of Slavic Languages and Literatures 44: 5-20.

Testa, Carlo (2002). Masters of Two Arts: Re-creation of European Literatures in Italian Cinema. Toronto: Toronto University Press.

Tomaszkiewicz, Teresa (2006). Przekład audiowizualny. Warszawa: Wydawnictwo Naukowe PWN.

Toury, Gideon (1986). “Translation. A Cultural-Semiotic Perspective”. In: Encyclopedic Dictionary of Semiotics. Ed. Thomas A. Sebeok. Vol. 2 (1111-1124). Berlin: Mouton de Gruyter.

Trivedi, Harish (2007). "Translating Culture vs. Cultural Translation". In: In Translation - Reflections, Refractions, Transformations. Eds. Paul St.-Pierre, Prafulla C. Kar. (277-287). Amsterdam-Philadelphia: John Benjamins [first published in: $91^{\text {st }}$ Meridian 4 (1) (May), 2005].

Webster, Noah (1993). Webster's Third New International Dictionary of the English Language, Unabridged. Ed. Philip B. Gove. [Köln]: Könemann.

Weissbrod, Rachel, Ayelet Kohn (2015). "Re-illustrating Multimodal Texts as Translation: Hebrew Comic Books Uri Cadduri and Mr. Fibber, the Storyteller". New Readings 15: 1-20.

Wiercińska, Janina (1986). Sztuka i ksiażka. Warszawa: PWN.

Wilkoń, Józef, Agata Hołobut (2009-2010). "Sztuka akompaniamentu". Z Józefem Wilkoniem rozmawia Agata Hołobut [Interview with Józef Wilkoń by Agata Hołobut]. Przekładaniec: A Journal of Literary Translation 22-23: 295-306.

Wysłouch, Seweryna (2007). "Ekfraza czy przekład intersemiotyczny?". In: Od tematu do rematu. Przechadzki z Balcerzanem. Eds. Tomasz Mizerkiewicz, Agata Stankowska. (489-504). Poznań: UAM.

Zawadzka, Magdalena (2009). “Jak przetłumaczyć obraz? Próby przekładu Figures Jeana Tardieu". In: Imago Mundi: 50 lat polskiej translatoryki. Eds. Krzysztof Hejwowski, Anna Szczęsny, Urszula Topczewska. (213-221). Warszawa: Instytut Lingwistyki Stosowanej Uniwersytetu Warszawskiego.

Аесьмян, Болеслав (2006). Безлюдная баллада или Слова для песни без слов. Поэзия. Teamp. Проза. Ed. А. Базилевский. Москва: РИПОЛ классик - Вахазар - WSH w Pułtusku. 